\title{
Relative Impacts of Methylammonium Lead Triiodide Perovskite Solar Cells Based on Life Cycle Assessment
}

Jaume-Adrià Alberola-Borràs, ${ }^{a}$ Rosario Vidal,, ${ }^{\mathrm{a},}$ Emilio J. Juárez-Pérez, ${ }^{\mathrm{b}, 1}$ Elena MasMarzá, ${ }^{\mathrm{b}}$ Antonio Guerrero, ${ }^{\mathrm{b}}$ and Iván Mora-Serób,

a Department of Mechanical Engineering and Construction, GID, Universitat Jaume I, Av. Sos Baynat s/n, 12006 Castellón, Spain

${ }^{\mathrm{b}}$ Institute of Advanced Materials (INAM), Universitat Jaume I, Av. Sos Baynat, s/n, 12006 Castellón, Spain

*Corresponding author. E-mail: vidal@uji.es, sero@uji.es

(C) 2017. This manuscript version is made available under the CC-BY-NC-ND 4.0 license http://creativecommons.org/licenses/by-nc-nd/4.0/

https://doi.org/10.1016/i.solmat.2017.11.008

${ }^{1}$ Current position: Okinawa Institute of Science and Technology, Energy Materials and Surface Sciences Unit, 1919-1 Tancha, Onna, Kunigami District, Okinawa Prefecture 904-0495, Okinawa, Japan 


\begin{abstract}
The environmental performance of four different device assembly procedures based on hybrid halide perovskite solar cell (PSC) were assessed from cradle to grave using life cycle assessment (LCA) methodology. In addition, a new environmental indicator was defined to measure the time evolution of an impact category, specifically in this case, human toxicity cancer payback time. PSCs procedures accounted for the probably three more used basic recipes for laboratory perovskite deposition: 1) spin coating of stoichiometric precursor solution, 2) spin coating of precursor solution using lead chloride precursor and 3) the two step deposition method. Also, the two most widely used substrate configurations (planar and mesoporous substrate) were considered. LCA included three realistic scenarios for the end of life: 1) residual landfill, 2) reuse and residual landfill and 3) reuse and recycling. The remaining variable parameters to assemble the device were fixed in common for all four devices, which were the major responsible of the whole PSC impact. Lead of PSCs had no significant contribution in environmental impacts. Beyond shared procedure steps, impacts generated by the twostep method and the use of mesostructured type substrate were higher. End of life scenario with reuse and recycling improved the toxicity impact categories.
\end{abstract}

\title{
Keywords
}

Life Cycle Assessment (LCA), Perovskite solar cells (PSC), Power conversion efficiency (PCE), Human toxicity, Lead, human toxicity cancer payback time

\section{Abbreviations}

EOL, end of life; EPBT, energy payback time; HTC, human toxicity, cancer; HTN-C, human toxicity, non-cancer; ET, Ecotoxicity; AD mineral and fossil resources depletion potential; WDP, water depletion potential; CED, cumulative energy demand; GWP, global warming potential; S1, scenario 1; S2, scenario 2; S3, scenario 3; HTCPBT, human toxicity cancer payback time; HTCPBT20, human toxicity payback time supposing a 20-year lifetime

\section{Graphical Abstract}

Common relative impacts

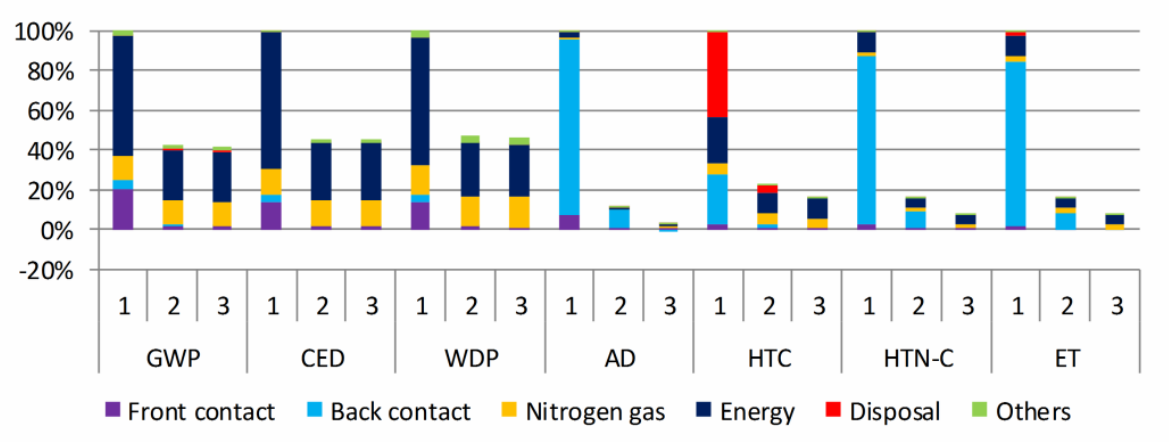




\section{Introduction}

Perovskite solar cells (PSCs) have emerged as a very efficient type of solar cells for the last few years. As yet, they have shown efficiencies $(\eta)$ over $20 \%$ on thin film cells $[1,2]$. Besides, it is expected they reach as high efficiencies as first-generation $(25.3 \%$ for a single crystal Si non-concentrator cell) and second-generation (22.6\% for a CIGS cell) solar cells do, even overstepping their efficiencies in a nearby future [3]. Owing to its versatility and the possibility of tailoring its energy band gap, perovskite also has a high potential to be combined with other materials to form a tandem device, thus reaching higher efficiencies [4]. For instance, an efficiency of $27 \%$ of a tandem of perovskite combined with Si was reported [5]. However, for a final implantation of this technology, demonstration of long term stability will be needed. Moreover, a technical and economical assessment of PSCs states that there are some limitations when manufacturing them at large scale [6]. Although stability should still be proven over a broad range of conditions [3], promising results have already been delivered [7].

One of the main concerns of PSCs is that the hybrid organic-inorganic perovskite most commonly used (with general formula $\mathrm{MAPbX}_{3}$, where $\mathrm{MA}=$ methylammonium and $\mathrm{X}=\mathrm{I}, \mathrm{Br}$ ) contains significant quantities of lead. $\mathrm{Pb}$ is a toxic substance whose intake in the human body causes damage through mimicry of essential ions such as $\mathrm{Ca}, \mathrm{Zn}$ and Fe [8,9]. Furthermore, its use is restricted by the European Restriction of Hazardous Substances Directive [10]. Encapsulation of PSCs, to impede contact with moisture and oxygen to improve stability [11], could be a solution for the toxicity issue in order to contain possible $\mathrm{Pb}$ leachates. Besides the toxicity of this element, the $\mathrm{Pb}$ extraction consists of a high-temperature process over $1400{ }^{\circ} \mathrm{C}$, which generates greenhouse gases and dangerous fumes as by-products [12]. Consequently, further solutions should be found in order to decrease the environmental impacts of the preparation of PSCs $[13,14]$.

Solar cells employing hybrid halide perovskite as light harvester material are mainly composed either a) by a thin film perovskite layer, known as planar configuration or b) by the perovskite deposited onto a mesoporous scaffold. The light harvesting layer is sandwiched between a hole transporting material (HTM) and an electron transporting material layer (ETM), see Figure 1. Once the charges are photo-generated in the perovskite, the ETM separates selectively the electrons to the front contact, and the HTM layer transports the holes to the back contact. Both layers are important to ensure a high performance of the cell, although different architectures are possible [15]. The most currently used material for the HTM is the Spiro-MeOTAD, initially synthesized for incorporating in multilayer light-emitting diodes (LED) [16,17], later it was used in solid state dye sensitized solar cell as HTM [18]. A compact layer of $\mathrm{TiO}_{2}$ is widely used as ETM which is formed in most of the cases through the hydrolysis of the titanium isopropoxide [19]. In PSCs, the front contact or light side is generally the transparent conductive oxide $\mathrm{SnO}_{2}: \mathrm{F}$ (FTO), because of its high transparency in the visible region and its low resistivity at room temperature of the order of $1 \Omega \mathrm{cm}$ [20]. Meanwhile, the back contact extracting contact may be made of silver [21], gold [22] or aluminum [23], among others. 

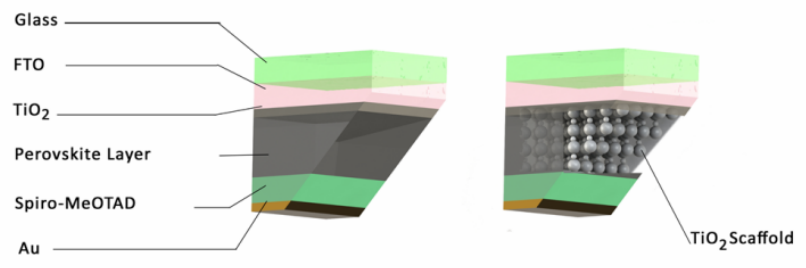

Figure 1. Perovskite solar cells layers: 1) thin film planar perovskite layer and 2) embedded perovskite in the mesoporous layer.

In order to lead the manufacture of this promising technology of PSCs to a more sustainable state, as it is still under development at lab-scale, life cycle assessment (LCA) methodology should be applied. In this regard, few works have been done thus far [6,8,14,24-29]. Amongst them, special emphasis should be given to the work of Espinosa et al. [24], in which two important deposition methods (spin-coating and vapor-deposition) were compared. With each deposition method, a different architecture (normal and inverted) was produced and assessed from cradle to gate. Gong et al. [30] compared two PSCs with different ETM ( $\mathrm{TiO}_{2}$ scaffold vs $\mathrm{ZnO}$ thin film), back contact (gold vs silver) and front contact (fluorine doped tin oxide vs indium tin oxide). This study was the first to include the disposal stage into its system boundary. Zhang et al. [31] evaluated a PSC based on titanium dioxide nanotubes through LCA methodology with data obtained from laboratory-scale. Alternatively, Celik et al. [26] evaluated a comparison of co-evaporation and spray perovskite deposition methods, which are more amenable to manufacturing, rather than laboratory specific deposition methods dipping and spinning. Recently, a perovskite/Si was assessed through LCA from cradle to grave [28] contrasting several combinations of materials for the back electrode (Au, Ag and Al) and HTM (Spiro-MeOTAD vs PEDOT:PSS). Finally, five different perovskites were compared using $\mathrm{Cs}$, formamidinium (FA), and MA for the monovalent cationic position; $\mathrm{Pb}$ and $\mathrm{Sn}$ for the cationic position; and combinations of $\mathrm{I}, \mathrm{Br}^{-}$and $\mathrm{Cl}^{-}$for the anionic position [29].

The aim of our work was to conduct a comprehensive LCA of four different devices of PSCs from cradle to grave [32,33], selecting likely the most broadly considered. Although the best efficiencies have been reached using perovskites with mixtures of organic cations $\left(\mathrm{MA}^{+}\right.$and $\mathrm{FA}^{+}$) and halides ( $\mathrm{I}^{-}$and $\mathrm{Br}$ ) [34,35], for the sake of clarity and simplicity, we just considered the most extended $\mathrm{CH}_{3} \mathrm{NH}_{3} \mathrm{PbI}_{3}$ halide perovskite as light absorbing material and three basic recipes of perovskite deposition: 1) spin coating of stoichiometric precursor solution of $\mathrm{PbCl}_{2}$ and methylammonium iodide (MAI) in 1:3 molar ratio, that we call Device 1 hereafter [36]; 2) spin coating of precursor solution of $\mathrm{PbI}_{2}$ and MAI, Device 2 hereafter [37]; and 3) the two step method deposition, which implies the dipping of a spin coated $\mathrm{PbI}_{2}$ film into a MAI solution (Device 3 hereafter) [38]. Also, for the preparation method of spin coating of precursor solution of $\mathrm{PbI}_{2}$ and MAI, the two most widely used substrate types (planar and with mesoporous $\mathrm{TiO}_{2}$ scaffold) were considered, the device with mesoporous substrate is called Device 4 [39]. The remaining variables parameters, as substrate, contacts, ETM and HTM, to assemble the device were fixed in common for all four types of devices, and correspond to the most commonly used in PSCs field, see Table 1. Due to the unreliable nature of the amount of electricity consumed in the laboratory environment for a real industrial scenario, an uncertainty analysis was performed for the most energy consuming processes. 
For the first time, we dipped into three possible scenarios of recycling of the PSCs, which could significantly improve their lifetime, see Table 1. In scenario 1, PSCs was inertized and deposited in a residual landfill. The other two scenarios were aimed by recent researches about the potential regeneration of PSCs [40,41] and they two differ in their potential treatment at the end of the last regenerative cycle: landfilling in scenario 2 or recycling in scenario 3 .

By means of the power conversion efficiencies (PCE) provided in the bibliography relative to each perovskite solar cell preparation studied [36-39], the lifetime at which each PSC produces just as much energy as necessary to manufacture it (in laboratory environment) was determined. Further analyses were performed considering that all four devices were prepared with an efficiency of $20 \%$ with different scenarios of end of life. Finally, a similar assessment was made to compare the payback time of the human toxicity impact category on the four PSC devices analyzed during their potential lifetime. This latter human toxicity cancer payback time analysis was contrasted with a similar analysis for established photovoltaic technologies.

\section{Materials and methods}

\subsection{Goal and scope definition}

This study was intended to lay on the table the environmental aspects of the most promising ways through which lead halide perovskite solar cells can be conducted. Four different perovskite based devices were considered, see Table 1. The four different analyzed devices presented different light harvesting layer but the other parts of the cell were common. We considered a glass with FTO deposited via sputtering. On FTO, a compact layer of $\mathrm{TiO}_{2}$, deposited via spin-coating worked as ETM. The next layer was the perovskite, prepared following three different procedures, and considering both planar and mesoporous $\mathrm{TiO}_{2}$ scaffold configurations, see Table 1. Spin-coated SpiroMeOTAD on top of perovskite layer was used as HTM. Finally, Au electrode was subsequently evaporated on the top of the HTM, see Figure 1. This common system shared the same impacts and they were relatively very high, as we discuss below. To analyze deeply the differences within the four cells, the common system was isolated and on one hand the environmental assessment of the common parts was performed and on the other hand, the environmental assessment of the four devices focused on their differences was also implemented.

Table 1. Characteristics of the different PSCs analyzed.

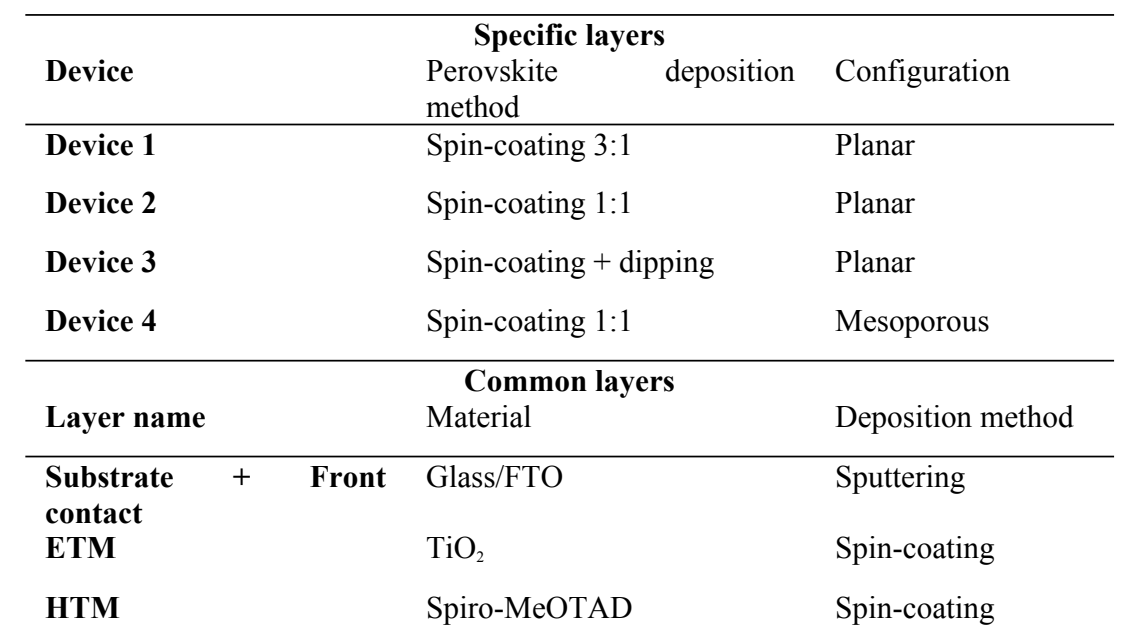




\begin{tabular}{lll} 
Back contact & Gold & $\begin{array}{l}\text { Thermal } \\
\text { evaporation }\end{array}$ \\
\hline Scenario & $\begin{array}{l}\text { End of life scenarios } \\
\text { Number of uses }\end{array}$ & EOL treatment \\
\hline Scenario 1 & 1 & Landfill \\
Scenario 2 & 10 & Landfill \\
Scenario 3 & 10 & Recycling \\
\hline
\end{tabular}

All four devices present common layers prepared in the same way and using the same materials while the difference is the light absorbing perovskite deposition and method and configuration

The study was performed on laboratory prepared solar cells. This fact allowed us to directly measure the consumptions during the solar cell preparation process. Despite this approach, we consider that important consequences for a future upscaling an implementation in an industrial environment can be extracted from this work. Functional unit was $1 \mathrm{~cm}^{2}$ of active surface area, assigning, for a first study, to each kind of device the efficiency reported in the literature under standard solar irradiation (AM1.5G), which depends on the type of perovskite solar cell preparation [36-38,42]. All devices had an active cell area of $4 \mathrm{~cm}^{2}$ and a cell's substrate area of $25 \mathrm{~cm}^{2}$. A general description of the system boundary of the four different devices is illustrated on Figure 2.

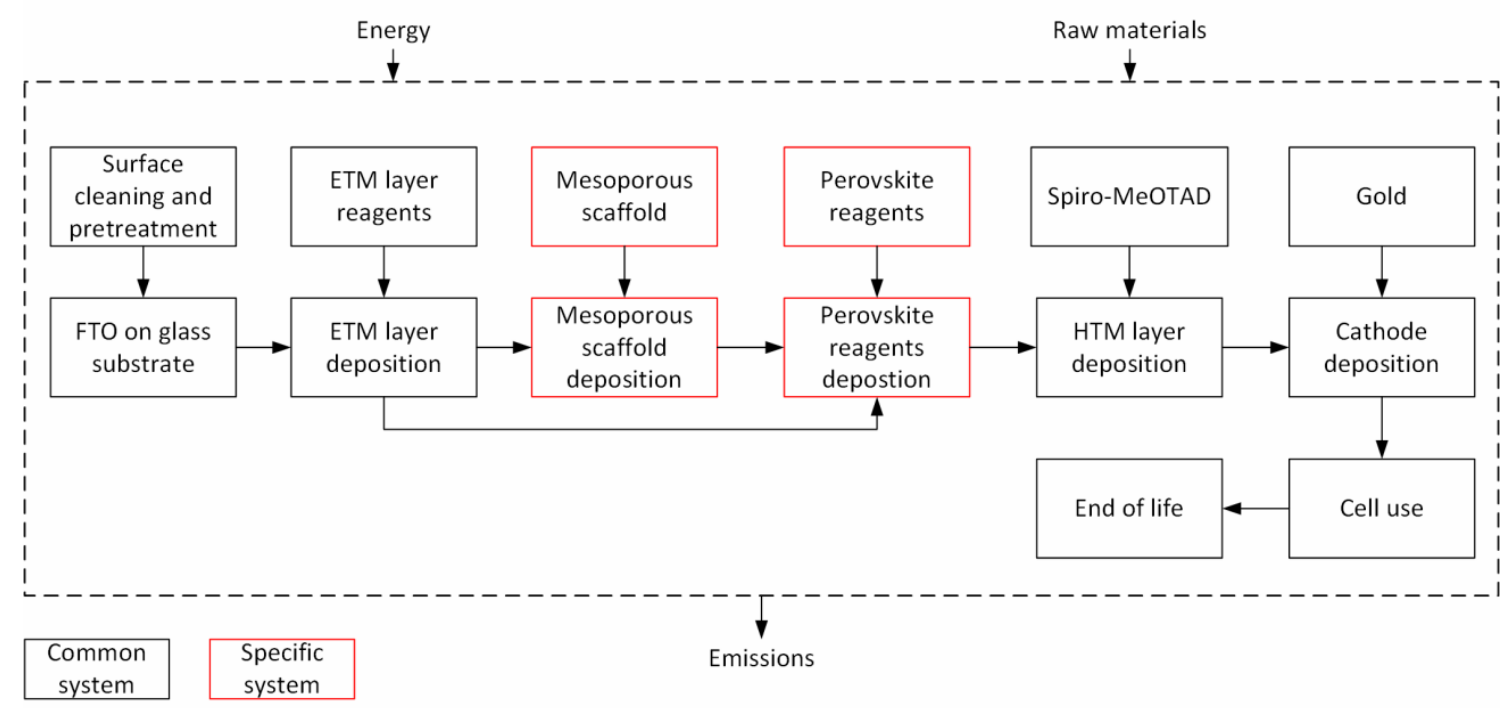

Figure 2. System boundary of the PSCs.

\subsection{Life cycle inventory}

Life cycle inventory included PSCs synthesis, cell use and end of life. Most inventory data was provided directly from our lab measures, see Supplementary material for synthesis details and life cycle inventories of the common system and the specific layers of perovskite.

Physical characteristics and other inventory data were obtained from literature [36-38,42-46]. The energy consumption needed in each step of the PSCs preparation 
was experimentally established by measuring the electric consumption. However, on those cases where the power consumption could not be measured, such as the FTO sputtering, vapor-deposition process and the use of glovebox, the data was obtained from the literature $[45,46]$ and the devices design characteristics. The environmental impacts generated by the electric consumption were calculated from the medium voltage production in Europe (RER data set of Ecoinvent database) [47]. Nitrogen gas consumption of the glove box, both for the PSC production process and for the reagents synthesis, was obtained from literature [24]. The contribution of transportation of every material of the inventory was obtained from the distance between the supplier and the manufacturing location, taking as reference our laboratory location.

While using the solar cells to cleanly convert sunlight to electricity, there is not any type of harm to the environment. Therefore, at this stage it is important to convert as much energy as possible to environmentally recover the energy invested in the manufacturing of the solar cell. This aim can be improved by enhancing the PCE, because the higher the PCE is, the lesser the EPBT. In the same manner, high PCE values are also important to produce as much electricity as possible to enable the covering of the energetic worldwide demand. Another way of converting more electricity entails increasing the lifetimes of PSCs to obtain more energy from one single device. Currently, lifetimes of PSCs are below 1 month, which is far from a desirable time. This is the reason behind the fact that stability of PSCs must be improved, leading more efforts towards this issue.

Three scenarios were considered for the end of life, see Table 1 and Supplementary material for their life cycle inventories. As well as in the LCI of the production process of the PSCs, some layers were considered common for the four devices, thus, the corresponding perovskite layers were considered specific of each device. A consequential approach was applied to model the benefits of recycling. This means that by-products of the disposal process are assumed to substitute a product manufactured by alternative means and that the environmental impacts thereby avoided are credited to the system under study [48], see Table 3 of the Supplementary material. Life cycle inventory of the residual landfilling of each waste fraction and incineration of the nonhazardous wastes were modelled with the tool provided by Doka [49].

\subsection{Impact categories selection}

Lead is a toxic substance whose use is restricted by the European Restriction of Hazardous Substances Directive. For this reason, toxicity was one of the most significant impact categories to be assessed. UNEP-SETAC toxicity (USEtox) model [50] is according with Hauschild et al. [51], Pizzol et al. [52], etc., the best among existing characterization models for toxicity. The three impact categories of USEtox model were selected: human toxicity, cancer effects (HTC); human toxicity, non-cancer effects (HTN-C) and ecotoxicity (ET).

The solar cells considered used other metals like Pd, Sn, Au, etc. (as part of the cell or involved in the preparation of the cell materials), and also fossil fuels (for energy, transport and as raw materials for synthesis of other compounds). The model CML 2002 [53], from the Institute of Environmental Sciences (CML), is one of the best among existing characterization models for scarcity [51]. To show the consumption of mineral resources, energy and water, the environmental impact of abiotic depletion potential was selected with the division into mineral and fossil resources depletion potential (AD) and water depletion potential (WDP). 
The cumulative energy demand (CED) was also selected for an ease energy comparisons. CED assessment was based on the method published by Ecoinvent ${ }^{\circledR}[54]$ and expanded within the SimaPro ${ }^{\circledR}$ software application.

Finally, the most important impact categories related with energy were also important. Global warming (GWP) is the most frequent impact category in life cycle assessments of energy. At midpoint level, Climate Change baseline model of 100 years of the Intergovernmental Panel on Climate Change (IPCC) is the reference model [55]. The version of USEtox, scarcity model of CML and climate change of the IPCC included in the International Reference Life Cycle Data System (ILCD) [56] were used. ILCD and CED are incorporated within the SimaPro ${ }^{\circledR}$ 8.0.3.14 software.

\section{Results and discussion}

\subsection{Environmental impact of the common system}

Table 2 and Figure 3 present the results of the environmental impacts of the common system equal in the four devices analyzed, whose associated inputs and outputs are the same for all of them. The results in Figure 3 are presented for the three end of life scenarios assessed. In order to make the results comparable, each impact category is related to the values for scenario 1 . These results allow readers to identify the hotspots of a PSC not taking into account the specific systems impact. In the category others of Figure 3 are included the inputs/outputs with values lower than $5 \%$ in every impact category (ETM, HTM, transportation, process outputs and inputs to reuse the devices). It has to be noticed that use phase is not included.

\section{Common relative impacts}

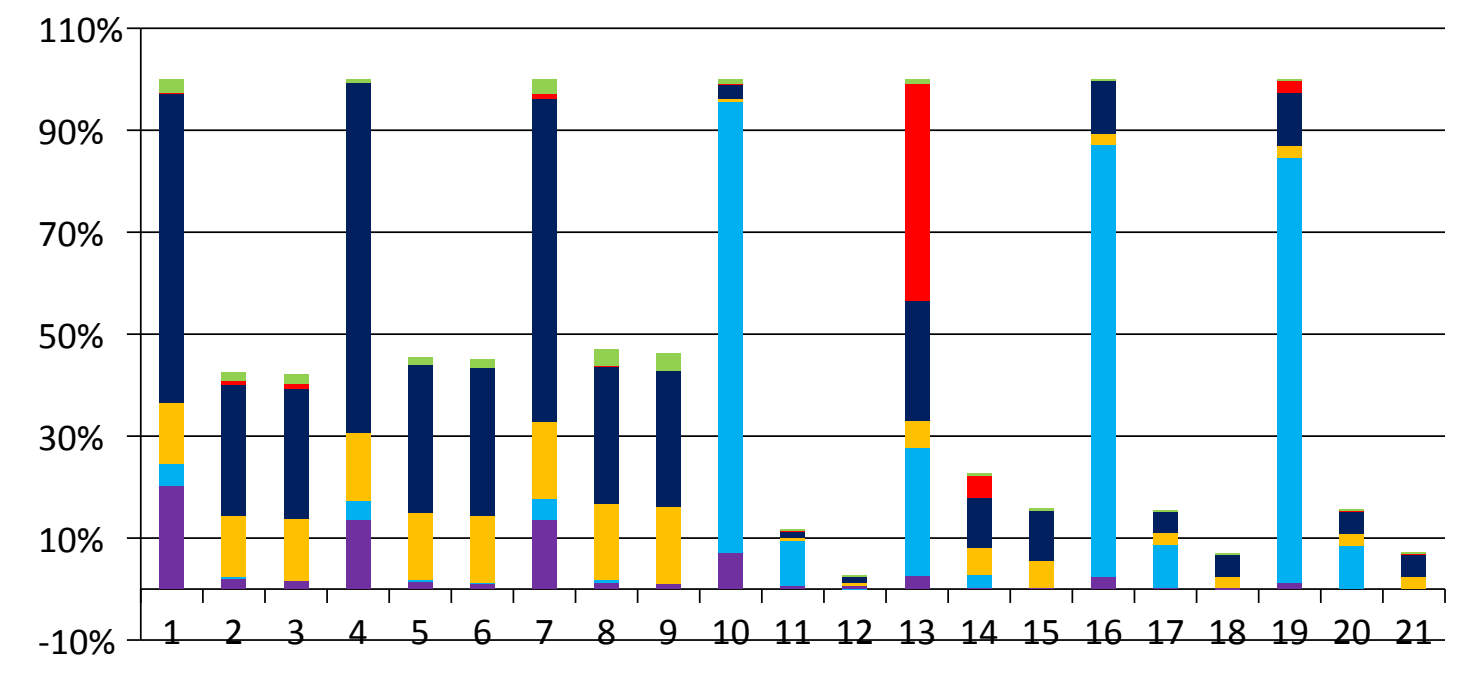

Front contact Back contact Nitrogen gas Energy Disposal Others

Figure 3. Relative impacts of the common part of the four devices, perovskite layer that differs from device to device are excluded in this analysis. Each impact category is analyzed for the three different scenarios for the end of life. Scenario 1: residual landfill, Scenario 2: reuse and residual landfill and Scenario 3: reuse and recycling.

The results showed the predominant impact of back contact for mineral and fossil depletion, human toxicity non-cancer and ecotoxicity. Back contact was made of gold, whose extraction procedure releases many toxic chemicals to the environment (cyanide 
and mercury, among others) and consumes many natural resources [57-59]. In scenario 3 , the impact reductions were significant as a consequence of its reuse and recycling. Although to a lesser extent, the impacts for these categories of the back contact were also reduced in the scenario 2 thanks to its reuse.

Laboratory production of PSC required high electric energy consumption. Burdens of electricity production [60-62] were the main hotspots in global warming, cumulative energy demand and water depletion. The front contact and the nitrogen gas contributed to these three impact categories as well, due to the high energy consumption during their production. Energy consumption was also notably present on toxicity impact categories.

The fact that the Au impact was predominant for the common system is in line with the results obtained by Gong et al. [30]. As the impacts of the common system were much higher (Table 2) than the impacts of the perovskite layer, the impacts produced by Au and also the energy consumption can be considered predominant on the whole cell. However, for Gong et al. [30], life cycle energy inventory was lower and in consequence climate change and cumulative energy demand impact categories were lower.

Disposal has not been usually included in LCA of perovskites, except in Gong et al. [30], however disposal of the common part was responsible of about $40 \%$ in HTC impact category for scenario 1. Reuse with final disposal or recycling reduced every impact category in different rate. Two groups of impact categories with different behaviors were observed. Global warming, cumulative energy demand and water depletion were included in the first group, in which values for scenario 2 and scenario 3 were almost the same, they were $42-47 \%$ respect values of scenario 1 . Decision about disposal or recycling at the end of the ten reuses was not significant for these impact categories.

Mineral and fossil depletion and toxicity impact categories were included in the second group, in which values for scenario 2 were decreased to 15.7 respect scenario 1 (AD) and the reduction was even higher in scenario 3 (the highest improvement was for AD, values decreased to $2.8 \%$ ). Recycling for these impact categories was clearly favored at EOL.

\subsection{Comparative assessment}

Table 2 includes the impacts of the non-common part (i.e. perovskite layer and $\mathrm{TiO}_{2}$ mesoporous layer for Device 4) of each type of perovskite solar cell in the seven impact categories selected for scenario 1. The percentages of contribution of each specific system in respect to contribution of the common system were calculated to help to visualize the specific weight for each device.

Table 2. Impacts for the common system and specific for the four devices.

\begin{tabular}{lllllll}
\hline $\begin{array}{l}\text { Categor } \\
\mathbf{y}\end{array}$ & Unit & $\begin{array}{l}\text { Common } \\
\text { system }\end{array}$ & $\begin{array}{l}\text { Specific for } \\
\text { Device1 }\end{array}$ & $\begin{array}{l}\text { Specific for } \\
\text { Device 2 }\end{array}$ & $\begin{array}{l}\text { Specific for } \\
\text { Device 3 }\end{array}$ & $\begin{array}{l}\text { Specific for } \\
\text { Device 4 }\end{array}$ \\
\hline GWP & $\mathrm{kg} \mathrm{CO}$ eq & $3.5410^{-2}$ & $5.1710^{-4}$ & $6.6410^{-4}$ & $1.3610^{-2}$ & $9.5110^{-3}$ \\
& $\%$ & - & 1.44 & 1.84 & 27.81 & 21.19 \\
& & & & & & \\
CED & MJ & $6.4910^{-1}$ & $1.0710^{-2}$ & $1.3810^{-2}$ & $2.8310^{-1}$ & $1.9710^{-1}$
\end{tabular}




\begin{tabular}{lllllll} 
& $\%$ & - & 1.62 & 2.08 & 30.36 & 23.33 \\
WDP & $\mathrm{m}^{3}$ water eq & $2.0810^{-4}$ & $3.5010^{-6}$ & $4.2110^{-6}$ & $8.3910^{-5}$ & $5.8810^{-5}$ \\
& $\%$ & - & 1.65 & 1.98 & 28.73 & 22.04 \\
AD & kg Sb eq & $3.2010^{-6}$ & $3.4610^{-9}$ & $3.2510^{-9}$ & $5.7410^{-8}$ & $4.1110^{-8}$ \\
& $\%$ & - & 0.11 & 0.10 & 1.76 & 1.27 \\
\multirow{2}{*}{ HTC } & CTUh & $6.4910^{-9}$ & $3.6710^{-11}$ & $4.7210^{-11}$ & $9.7010^{-10}$ & $6.7710^{-10}$ \\
& $\%$ & - & 0.56 & 0.72 & 13.00 & 9.44 \\
HTN-C & CTUh & $5.4810^{-8}$ & $1.3610^{-10}$ & $1.7410^{-10}$ & $3.5610^{-9}$ & $2.4910^{-9}$ \\
& $\%$ & - & 0.25 & 0.32 & 6.11 & 4.34 \\
ET & CTUe & 1.30 & $3.710^{-3}$ & $4.2010^{-3}$ & $8.6210^{-2}$ & $6.0110^{-2}$ \\
& $\%$ & - & 0.5 & 0.32 & 6.23 & 4.43 \\
\hline
\end{tabular}

The results of Table 2 show that, in every case, impacts of the specific part of each device type were much lower than impacts of the common system, shared by all four different devices analyzed. A larger number and amount of common inputs may justify such results, even though the specific part contains $\mathrm{Pb}$. Furthermore, the high impact produced by the back contact and the energy consumption in the common part may overshadow the contribution of all the specific parts. Interestingly, the fact that specific parts had a lower impact in all of the impact categories suggests that $\mathrm{Pb}$ content of the perovskite solar cells does not currently constitute a concerning hotspot, in good agreement with J. Zhang et al. [31] and N. Espinosa et al. [24].

Impacts generated by Devices 3 and 4 were much higher than impacts generated by Devices 1 and 2, as a consequence of more complex processes involved and higher energetic consumption. A closer comparison between Devices 1 and 2 showed that impacts were slightly higher for Device 2 in all the categories except in mineral and fossil depletion impact category where Device 2 contribution was vaguely lower. The reason behind the higher impact in almost all categories was a more quantity of energy and reagents consumption.

Continuing with the specific systems of the different devices, a comprehensive evaluation of their inputs is presented in Figure 4 for human toxicity cancer and cumulative energy demand impact categories and for scenario 1. Impacts are divided in perovskite layer, energy consumption, disposal at EOL and others (transportation, process outputs and scaffold for the Device 4). 


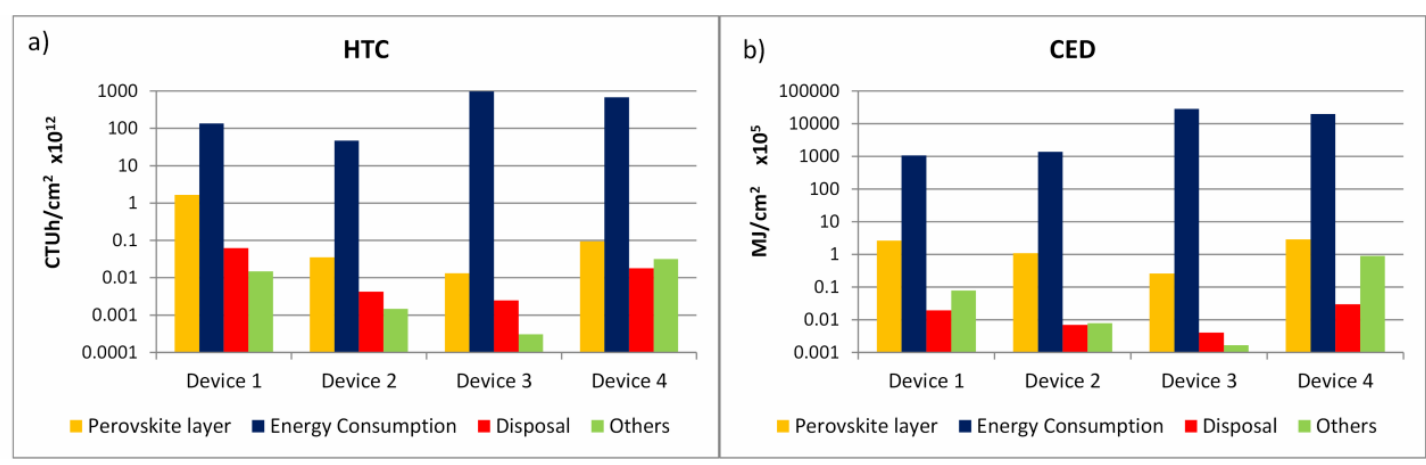

Figure 4. Specific impacts for scenario 1: a) Human toxicity cancer; b) Cumulative energy demand. Vertical axis is in logarithmic scale.

Figure 4 shows that the energy consumption in solar cell synthesis is quite prominent, with few orders of magnitude higher in all of the categories. For this reason, vertical axis is represented in logarithmic scale. Again, this fact proved that energy consumption was the main responsible of most of the impacts generated producing a PSC. This result is in agreement with previous works (Zhang et al. [31] and N. Espinosa et al. [24]) and opposite to that of Asif et al. [6]. Energy consumption is a hotspot to be improved substantially in industrial production.

Figure $4 \mathrm{a}$ focuses on the results of human toxicity cancer, a potential critical impact category as a consequence of the toxicity of lead. Considering the specific systems of the PSCs and excluding the energy consumption, Device 3 had the lowest impact thanks to it used the least amount of perovskite and the least amount of solvents. Such impact was mostly due to the $\mathrm{Pb}$ content of the perovskite. However, this specific impact due to the lead content was 1-2 orders of magnitude lower than the originated from the common system; consequently the content of $\mathrm{Pb}$ could not be considered the main source of human toxicity cancer of PSCs.

Another worth-focusing impact category for this study was CED. Figure 4b compares the inputs of the four PSC Devices. Again, excluding the energy consumption, Device 3 had the smallest impact and the perovskite layer predominated in the impact of the four Devices. Though, this time the impact was mostly generated by iodide production. CED was used to estimate the energy payback time for the four devices (included in the Supplementary material), the analysis reflected that Devices 3 and 4 (using two step deposition method and $\mathrm{TiO}_{2}$ scaffold respectively) can just compete in terms of energy payback time if they can provide higher efficiency than Devices 1 and 2, and even in that case, the stability of the device had to be long enough to allow the surpass.

The analysis of advantages or disadvantages of reuse with final disposal or final recycling is shown in Figure 5. The relative impacts of the specific part for scenarios 2 and 3 versus scenario 1 are represented in a way that the value $100 \%$ indicates no change regardless scenario 1. Impacts of the common part were not included. If a scenario of reuse was followed, Device 4 was the only one with significant improvement in all impact categories, due to the benefits of reusing the scaffold. Moreover, Device 4 can also compete respect energy payback time with Devices 1 and 2 if a recycling approach is followed (energy payback time included in the Supplementary Material).

This fact allowed us to conclude that reuse and recycling the $\mathrm{Pb}$ content of perovskites had no significant improvement in environmental impacts, although lead must always 
be safely disposed and avoid accidentals spillages. Taking into account all the PSC, reuse and recycling improved the environmental impacts due to the recovery of the materials present in the back contact and front contact, and the recovery of $\mathrm{TiO}_{2}$.

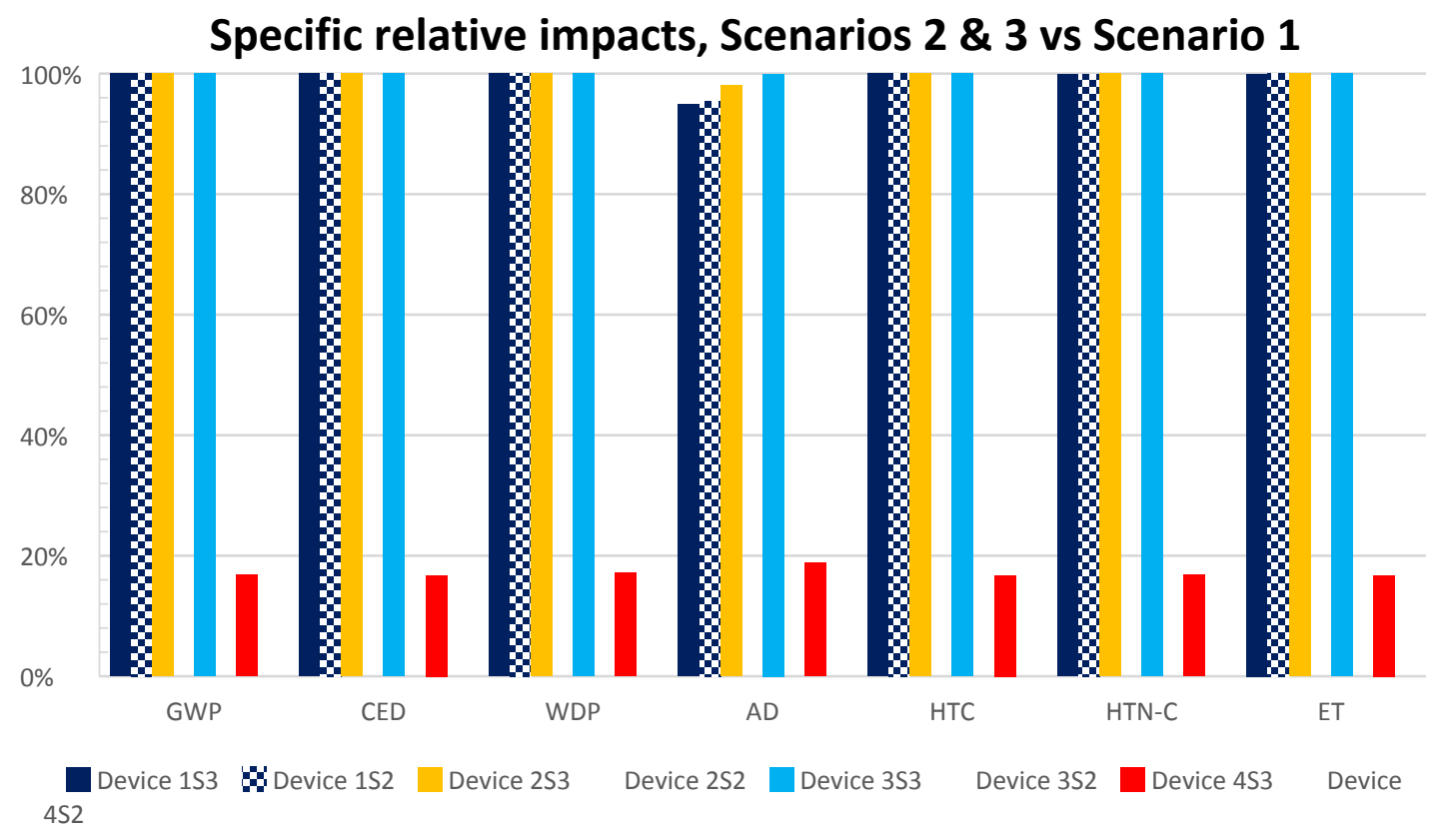

Figure 5. Specific relative impacts for scenario 2 vs. scenario1 (S2) and scenario 3 vs. scenario 1 (S3).

\subsection{Human toxicity cancer payback time}

A similar assessment as that made for the energy payback time (included in the Supplementary Material) was made to compare the time evolution of human toxicity cancer category impact or human toxicity cancer payback time, called here HTCPBT (Table 3 and Figure 6). Similar assessments should be performed with the rest of the impact categories. At the beginning, each device had the human toxicity cancer impact value corresponding to the materials and production phase. This impact category diminished as the solar cell produces energy, avoiding conventional electric power consumption. Concretely, the reduction $1 \mathrm{MJ}$ of electricity (medium voltage, production RER, at grid) avoided $9.92 \cdot 10^{-9} \mathrm{CTUh}$.

Table 3. Time evolution of the human toxicity cancer.

\begin{tabular}{lcccc}
\hline & Device 1 & Device 2 & Device 3 & Device 4 \\
\hline $\begin{array}{l}\text { Initial HTC } \\
\left.\text { (CTUh/cm }^{2}\right)\end{array}$ & $6.5310^{-9}$ & $6.5410^{-9}$ & $7.4610^{-9}$ & $7.1510^{-9}$ \\
$\begin{array}{l}\text { HTCPBT } \\
\text { (years) }\end{array}$ & 10.98 & 12.05 & 9.53 & 11.15 \\
$\begin{array}{l}\text { HTCPBT20S1 } \\
\text { (years) }\end{array}$ & 6.26 & 6.27 & 7.15 & 6.86 \\
$\begin{array}{l}\text { HTCPBT20S3 } \\
\text { (years) }\end{array}$ & 1.02 & 1.03 & 1.92 & 1.10 \\
\hline
\end{tabular}

HTCPBT was estimated with the PCE from the literature. HTCPBT20S1 and HTCPBT20S3 were calculated considering an efficiency of the device of $20 \%$ and scenario 1 and scenario 3, respectively, at EOL. 
The initial impact sets the position of each solar cell for smaller lifetimes, whilst the efficiency determines directly proportional the slope of the line to set the position of each type for larger lifetimes. While Device 1, 2 and 4 lasted approximately 11-12 years to recover the initial impact generated to produce them, Device 3 lasted approximately 9.5 years, if the efficiencies extracted from literature were considered. Also, this device avoided more human toxicity impact from the 6th year than the rest of solar cell types studied.

When efficiencies of $20 \%$ were considered for all four devices, the time they lasted to reach a negative human toxicity impact was obviously shorter. In a recycling approach and for the same efficiency, Figure 6c), human toxicity cancer payback time for Device 3 almost doubled the value for the other three devices, conversely, Device 4 presented similar values with Devices 1 and 2.
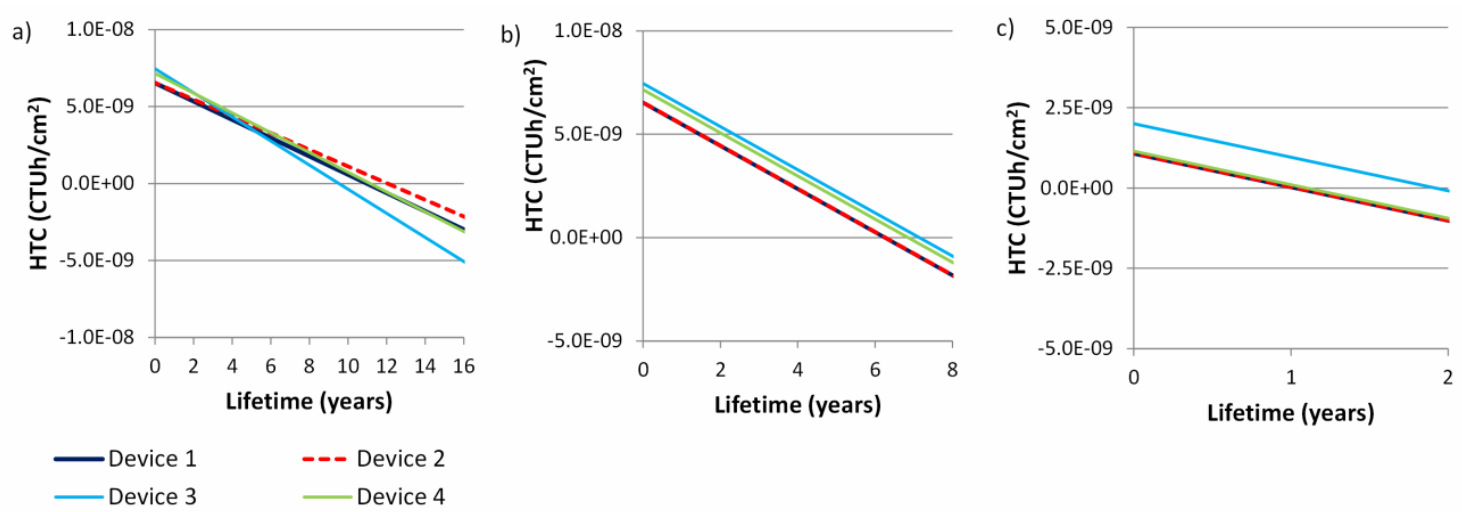

Figure 6. Time evolution of the human toxicity cancer: a) considering PCE from literature; b) considering $20 \%$ efficiency and scenario 1 at EOL; c) considering $20 \%$ efficiency and scenario 3 at EOL.

In order to make the HTCPBT analysis more straightforward to the readers, a comparison of established photovoltaic technologies is provided herein. The HTC impact of diverse established photovoltaic technologies is reported in some works [63-66]. For instance, the HTCPBT of PSCs is compared in this work with Organic photovoltaics (OPV) [64].

Here, the HTCPBT analysis was similarly performed as for the four PSCs studied in this work. For the purpose of estimating HTCPBT scores, the HTC impacts and efficiencies of OPV was taken from the work of Espinosa et al [64]. In contrast to the data in this manuscript, the efficiency and the inventory utilized for the analysis of established photovoltaic technologies correspond to modules instead of cells. Moreover, contrary to established photovoltaic technologies, PSCs of this study are produced in a laboratory environment, where they are not optimized as the common system of this manuscript evidences. These facts generate uncertainty to this analysis. Thanks to a $1.1 \%$ of efficiency for the OPV and an initial HTC impact of $2.2110^{-10} \mathrm{CTUh} / \mathrm{cm}^{2}$, this analysis reveals that the HTC generated during the life cycle of the OPV is recovered from 3.85 years, by avoiding usage of electricity from the grid.

This HTCPBT result clearly display that PSCs are worse than OPV. The reason behind this outcome is a shorter initial HTC, despite the lower efficiency. It is worth mention that in spite of the low HTCPBT of OPV of 3.85 years, it is still higher than current OPV lifetimes, which is inferior to 2 years [64].

\subsection{Sensitivity assessment}


As clearly depicted in Figure 3 and Figure 4, energy supposes the most detrimental flow by far. At a certain distance, it is followed by the nitrogen gas consumption. Therefore, it is expected that a reduction in these flows can modify the results. Either it can decrease the overall impact or alter which is the most adverse device.

Bearing in mind that the energy was measured experimentally from laboratory equipment whereby the energetic consumption is not optimized. Therefore, it is predicted that in an industrially produced device the energy consumed will decrease. In order to estimate the energy consumed in such industrial scenario the thermodynamic processes that the solar cell undergoes during its production were considered. Moreover, a complete thermal isolation of the system was supposed for the estimation. In order to analyze which device is the most harmful in a theoretical industrial scenario, a reduction in the energy usage of the specific system was simulated. In particular, five steps of the deposition of perovskite procedure were perceived as the most energy consuming, where the reduction was implemented. As shown in Table S4 of the Supplementary material, they are four annealing treatments practiced after the deposition of each reagent in device 3, and another annealing treatment after the deposition of the scaffold in device 4 . These processes generally consume one order of magnitude more energy than the rest. It is important to mention that the actual electricity consumption might be somewhere between the electricity measured experimentally and that estimated via thermodynamic phenomena. After obtaining the thermodynamically necessary energy for these treatments, its impact was added to the impact of the rest of impacts that have remained constant. The energy was estimated from the specific heat of the materials involved [67-70], along with the conditions at which the treatments were performed, as the energy spent to heat the materials was solely considered and no energy losses during the treatments were assumed. In order to show the outcomes of the drop in energy consumption, the relative HTC impact in the theoretical industrial scenario and the same impact in the scenario of electricity measured in laboratory equipment respect to the impact of the most pernicious device for each scenario were calculated. These results are presented in percentages for the four devices in Table 4 together with the absolute values of the HTC impact of the theoretical industrial scenario.

Table 4. Sensitivity assessment: Relative HTC values per device for the deposition of the four specific layers respect to the HTC value of the most harmful device for lab-measured and industrial scenarios and absolute HTC values for the industrial scenario.

\begin{tabular}{lcccc}
\hline & Device 1 & Device 2 & Device 3 & Device 4 \\
\hline $\begin{array}{l}\text { Relative lab-measured } \\
\text { HTC (\%) }\end{array}$ & 4 & 5 & 100 & 70 \\
$\begin{array}{l}\text { Relative industrial } \\
\text { HTC (\%) }\end{array}$ & 20 & 26 & 34 & 100 \\
$\begin{array}{l}\text { Industrial HTC } \\
\left(\mathbf{C T U h} / \mathbf{c m}^{2}\right)\end{array}$ & $3.6710^{-11}$ & $4.7210^{-11}$ & $6.3010^{-11}$ & $1.8510^{-10}$ \\
\hline
\end{tabular}

The results in Table 4 show that the most adverse device moved from Device 3 to Device 4 in the new theoretical industrial scenario, as Device 3 present the most relevant impact drop. Thanks to this impact decreasing for Device 3 together with the increasing of Device 1 and Device 2, these three devices impact is more similar for the theoretical industrial approach. Overall, from absolute values a significant reduction of HTC impact of the specific system of Device 3 and Device 4 is observed in comparison to the HTC scores in Table 2. In spite of the fact that differences in HTC impacts among devices were reduced relevantly, Device 3 and Device 4 keep presenting the most 
adverse HTC in respect to Device 1 and Device 2. Furthermore, with the reduction in consumption analyzed is not expected the overall impact of devices to decrease, because as the specific system is still lower than that of the common system. Among all devices studied, Devices 3 and 4 present the best efficiency results; hence it could be worth addressing an environmental improvement of their life cycle.

\section{Conclusions}

The environmental performance of four different laboratory-produced lead halide perovskite photovoltaic devices, with quite common and extended configurations was assessed from cradle to grave using life cycle assessment methodology. These procedures accounted for the three most commonly used basic recipes of perovskite deposition: 1) spin coating of precursor solution within excess of chloride, 2) spin coating of stoichiometric precursor solution and 3) the two step method deposition. The two most widely used cell configurations (planar and mesoporous) were considered. Furthermore, three scenarios for the end of life were assessed: 1) residual landfill, 2) reuse and residual landfill and 3) reuse and recycling. As far as we know it is the first time that such detailed analysis is performed for the end of life, and it has a significant effect in the energy and human toxicity cancer payback times.

Common system of the four solar cell devices was the major responsible of the impact of the whole PSC. Lead was not among the main current concerns of the use of PSCs, contrary to the most extended assumption that the lead contained in the perovskite is the main responsible of the impacts of PSC. This was so even for a theoretical industrial estimated case where the electricity consumption was diminished.

Considering the four analyzed devices with the same efficiency, Devices 1 and 2 had lower energy and human toxicity cancer payback times. Devices fabricated by the two step method (Device 3) or using $\mathrm{TiO}_{2}$ scaffold (Devices 4) can only compete in this categories in a scenario where they had higher efficiency and long enough stability in order to overcome the initial higher production cost and human toxicity generated during their fabrication. In addition, devices using $\mathrm{TiO}_{2}$ scaffold were specially benefited with recycling at EOL, achieving energy and human toxicity cancer payback times' equivalents to devices fabricated by the one step method.

PSCs constitute a promising technology to produce energy from the sunlight owing to their low cost and high performances, although much work has to be done in order to upscale, reduce energy consumption during production and moreover, PSCs have to increase their stability, which will play a key role to make them feasible for the massive production.

\section{Associated Content}

Supporting information. Details of the production system and inventory, and energy payback time analysis.

\section{Author Information}

\section{Corresponding Author}

*E-mail: vidal@uji.es, sero@uji.es 


\section{Present Addresses}

${ }^{1}$ Okinawa Institute of Science and Technology, Energy Materials and Surface Sciences Unit, 1919-1 Tancha, Onna, Kunigami District, Okinawa Prefecture 904-0495, Okinawa, Japan

\section{Author Contributions}

J.-A.A.-B. modelled reagents, collated data, and wrote the previous version of the manuscript. R.V. supervised the work, developed the end of life analysis, and wrote the final version of the manuscript. I.M.-S. proposed and supervised the work. E.J.J.-P. proposed the work and assisted the data collation. E.M.-M. and A.G. assisted the data collation.

\section{Notes}

The authors declare no competing financial interest.

\section{Acknowledgements}

The research leading to these results has received funding from MINECO of Spain under project MAT2013-47192-C3-1-R and Generalitat Valenciana under project ACOMP/2015/105.

\section{References}

[1] M.A. Green, K. Emery, Y. Hishikawa, W. Warta, E.D. Dunlop, Solar cell efficiency tables (version 47), Prog. Photovoltaics Res. Appl. 24 (2016) 3-11. doi:10.1002/pip.2728.

[2] National Renewable Energy Laboratory, Best Research-Cell Efficiencies, (2016). https://www.nrel.gov/pv/assets/images/efficiency-chart.png (accessed September 15, 2017).

[3] H.J. Snaith, Perovskites: The Emergence of a New Era for Low-Cost, HighEfficiency Solar Cells, J. Phys. Chem. Lett. 4 (2013) 3623-3630. doi:10.1021/jz4020162.

[4] R.F. Service, Perovskite Solar Cells Keep On Surging, Science. 344 (2014) 458-458. doi:10.1126/science.344.6183.458.

[5] I. Almansouri, A. Ho-Baillie, M.A. Green, Ultimate efficiency limit of singlejunction perovskite and dual-junction perovskite/silicon two-terminal devices, Jpn. J. Appl. Phys. 54 (2015) 08KD04. doi:10.7567/JJAP.54.08KD04.

[6] A.A. Asif, R. Singh, G.F. Alapatt, Technical and economic assessment of perovskite solar cells for large scale manufacturing, J. Renew. Sustain. Energy. 7 (2015) 43120. doi:10.1063/1.4927329.

[7] T. Leijtens, G.E. Eperon, N.K. Noel, S.N. Habisreutinger, A. Petrozza, H.J. Snaith, Stability of Metal Halide Perovskite Solar Cells, Adv. Energy Mater. 5 (2015) 
1-23. doi:10.1002/aenm.201500963.

[8] A. Babayigit, A. Ethirajan, M. Muller, B. Conings, Toxicity of organometal halide perovskite solar cells, Nat. Mater. 15 (2016) 247-251. doi:10.1038/nmat4572.

[9] C. Klaassen, Goodman and Gilman's The Pharmacological Basis of Therapeutics, in: A. Goodman, L. S. \& Gilman (Ed.), Goodman Gilman's Pharmacol. Basis Ther., 6th ed., Mcmillan, 1980: pp. 1615-1637. https://drive.google.com/file/d/OB7RoFpW2gyFU1IPd1VMQ1YtZnc/view?pref=2\&pli=1.

[10] EC, Directive 2002/95/EC of the European Parliament and of the Council of 27 January 2003 on the restriction of the use of certain hazardous substances in electrical and electronic equipment, Official Journal of the European Union, Brussels, Belgium, 2003. http://eur-lex.europa.eu/legalcontent/EN/NOT/?uri=CELEX:32002L0095.

[11] X. Li, M. Tschumi, H. Han, S.S. Babkair, R.A. Alzubaydi, A.A. Ansari, et al., Outdoor Performance and Stability under Elevated Temperatures and LongTerm Light Soaking of Triple-Layer Mesoporous Perovskite Photovoltaics, Energy Technol. 3 (2015) 551-555. doi:10.1002/ente.201500045.

[12] C.A. Sutherland, E.F. Milner, R.C. Kerby, H. Teindl, A. Melin, H.M. Bolt, Lead, in: Ullmann's Encycl. Ind. Chem., Wiley-VCH Verlag GmbH \& Co. KGaA, 2000. doi:10.1002/14356007.a15_193.pub2.

[13] P.-Y. Chen, J. Qi, M.T. Klug, X. Dang, P.T. Hammond, A.M. Belcher, Environmentally responsible fabrication of efficient perovskite solar cells from recycled car batteries, Energy Environ. Sci. 7 (2014) 3659-3665. doi:10.1039/C4EE00965G.

[14] A. Babayigit, D. Duy Thanh, A. Ethirajan, J. Manca, M. Muller, H.-G. Boyen, et al., Assessing the toxicity of $\mathrm{Pb}$ - and $\mathrm{Sn}$-based perovskite solar cells in model organism Danio rerio, Sci. Rep. 6 (2016) 18721. doi:10.1038/srep18721.

[15] E.J. Juarez-Perez, M. Wußler, F. Fabregat-Santiago, K. Lakus-Wollny, E. Mankel, T. Mayer, et al., Role of the Selective Contacts in the Performance of Lead Halide Perovskite Solar Cells, J. Phys. Chem. Lett. 5 (2014) 680-685. doi:10.1021/jz500059v.

[16] D. Marsitzky, J. Murray, J.C. Scott, K.R. Carter, Amorphous Poly-2,7-fluorene Networks, Chem. Mater. 13 (2001) 4285-4289. doi:10.1021/cm010282h.

[17] J. Salbeck, N. Yu, J. Bauer, F. Weissörtel, H. Bestgen, Low molecular organic glasses for blue electroluminescence, Synth. Met. 91 (1997) 209-215. http://www.scopus.com/inward/record.url?eid=2-s2.00031381007\&partnerID=tZOtx3y1.

[18] U. Bach, D. Lupo, P. Comte, J.E. Moser, F. Weissörtel, J. Salbeck, et al., Solidstate dye-sensitized mesoporous $\mathrm{TiO} 2$ solar cells with high photon-to-electron conversion efficiencies, Nature. 395 (1998) 583-585. doi:10.1038/26936. 
[19] D.A.H. Hanaor, I. Chironi, I. Karatchevtseva, G. Triani, C.C. Sorrell, Single and mixed phase TiO 2 powders prepared by excess hydrolysis of titanium alkoxide, Adv. Appl. Ceram. 111 (2012) 149-158. doi:10.1179/1743676111Y.0000000059.

[20] A.N. Banerjee, S. Kundoo, P. Saha, K.K. Chattopadhyay, Synthesis and Characterization of Nano-Crystalline Fluorine-Doped Tin Oxide Thin Films by SolGel Method, J. Sol-Gel Sci. Technol. 28 (2003) 105-110. doi:10.1023/A:1025697322395.

[21] J. Zhang, E.J. Juárez-Pérez, I. Mora-Seró, B. Viana, T. Pauporté, Fast and low temperature growth of electron transport layers for efficient perovskite solar cells, J. Mater. Chem. A. 3 (2015) 4909-4915. doi:10.1039/C4TA06416J.

[22] A. Listorti, E.J. Juarez-Perez, C. Frontera, V. Roiati, L. Garcia-Andrade, S. Colella, et al., Effect of Mesostructured Layer upon Crystalline Properties and Device Performance on Perovskite Solar Cells., J. Phys. Chem. Lett. 6 (2015) 1628-37. doi:10.1021/acs.jpclett.5b00483.

[23] J. You, Z. Hong, Y. (Michael) Yang, Q. Chen, M. Cai, T.-B. Song, et al., LowTemperature Solution-Processed Perovskite Solar Cells with High Efficiency and Flexibility, ACS Nano. 8 (2014) 1674-1680. doi:10.1021/nn406020d.

[24] N. Espinosa, L. Serrano-Luján, A. Urbina, F.C. Krebs, Solution and vapour deposited lead perovskite solar cells: Ecotoxicity from a life cycle assessment perspective, Sol. Energy Mater. Sol. Cells. 137 (2015) 303-310. doi:10.1016/j.solmat.2015.02.013.

[25] L. Serrano-Lujan, N. Espinosa, T.T. Larsen-Olsen, J. Abad, A. Urbina, F.C. Krebs, Tin- and Lead-Based Perovskite Solar Cells under Scrutiny: An Environmental Perspective, Adv. Energy Mater. $5 \quad$ (2015) 1501119. doi:10.1002/aenm.201501119.

[26] I. Celik, Z. Song, A.J. Cimaroli, Y. Yan, M.J. Heben, D. Apul, Life Cycle Assessment (LCA) of perovskite PV cells projected from lab to fab, Sol. Energy Mater. Sol. Cells. 156 (2016) 157-169. doi:10.1016/j.solmat.2016.04.037.

[27] I. Celik, Z. Song, M.J. Heben, Y. Yan, D.S. Apul, Life cycle toxicity analysis of emerging PV cells, in: 2016 IEEE 43rd Photovolt. Spec. Conf., IEEE, 2016: pp. 3598-3601. doi:10.1109/PVSC.2016.7750343.

[28] M. Monteiro Lunardi, A. Wing Yi Ho-Baillie, J.P. Alvarez-Gaitan, S. Moore, R. Corkish, A life cycle assessment of perovskite/silicon tandem solar cells, Prog. Photovoltaics Res. Appl. 25 (2017) 679-695. doi:10.1002/pip.2877.

[29] J. Zhang, X. Gao, Y. Deng, Y. Zha, C. Yuan, Comparison of life cycle environmental impacts of different perovskite solar cell systems, Sol. Energy Mater. Sol. Cells. 166 (2017) 9-17. doi:10.1016/j.solmat.2017.03.008.

[30] J. Gong, S.B. Darling, F. You, Perovskite photovoltaics: life-cycle assessment of energy and environmental impacts, Energy Environ. Sci. 8 (2015) 1953-1968. doi:10.1039/C5EE00615E. 
[31] J. Zhang, X. Gao, Y. Deng, B. Li, C. Yuan, Life Cycle Assessment of Titania Perovskite Solar Cell Technology for Sustainable Design and Manufacturing, ChemSusChem. 8 (2015) 3882-3891. doi:10.1002/cssc.201500848.

[32] ISO 14040:2006, Environmental management. Life cycle assessment. Principles and framework (14040: 2006), European Comittee for Standarization, Brussels, Belgium, 2006. http://www.iso.org/iso/catalogue_detail?csnumber=37456 (accessed February 10, 2015).

[33] ISO 14044:2006, Environmental management. Life cycle assessment. Requierements and guidelines (14044: 2006), European Comittee for Standarization, Brussels, Belgium, 2006. http://www.iso.org/iso/catalogue_detail?csnumber=38498 (accessed February 10, 2015).

[34] W.S. Yang, J.H. Noh, N.J. Jeon, Y.C. Kim, S. Ryu, J. Seo, et al., High-performance photovoltaic perovskite layers fabricated through intramolecular exchange, Science. 348 (2015) 1234-1237. doi:10.1126/science.aaa9272.

[35] D. Bi, W. Tress, M.I. Dar, P. Gao, J. Luo, C. Renevier, et al., Efficient luminescent solar cells based on tailored mixed-cation perovskites, Sci. Adv. 2 (2016) 1-7. doi:10.1126/sciadv.1501170.

[36] G.E. Eperon, V.M. Burlakov, P. Docampo, A. Goriely, H.J. Snaith, Morphological Control for High Performance, Solution-Processed Planar Heterojunction Perovskite Solar Cells, Adv. Funct. Mater. 24 (2014) 151-157. doi:10.1002/adfm.201302090.

[37] J.H. Noh, N.J. Jeon, Y.C. Choi, M.K. Nazeeruddin, M. Grätzel, S. II Seok, Nanostructured $\mathrm{TiO} 2 / \mathrm{CH} 3 \mathrm{NH} 3 \mathrm{PbI} 3$ heterojunction solar cells employing spiroOMeTAD/Co-complex as hole-transporting material, J. Mater. Chem. A. 1 (2013) 11842. doi:10.1039/c3ta12681a.

[38] J. Burschka, N. Pellet, S.-J. Moon, R. Humphry-Baker, P. Gao, M.K. Nazeeruddin, et al., Sequential deposition as a route to high-performance perovskitesensitized solar cells, Nature. 499 (2013) 316-319. doi:10.1038/nature12340.

[39] Y. Zhao, A.M. Nardes, K. Zhu, Solid-State Mesostructured Perovskite CH 3 NH 3 Pbl 3 Solar Cells: Charge Transport, Recombination, and Diffusion Length, J. Phys. Chem. Lett. 5 (2014) 490-494. doi:10.1021/jz500003v.

[40] B.J. Kim, D.H. Kim, S.L. Kwon, S.Y. Park, Z. Li, K. Zhu, et al., Selective dissolution of halide perovskites as a step towards recycling solar cells, Nat. Commun. 7 (2016) 11735. doi:10.1038/ncomms11735.

[41] L. Huang, Z. Hu, J. Xu, X. Sun, Y. Du, J. Ni, et al., Efficient electron-transport layerfree planar perovskite solar cells via recycling the FTO/glass substrates from degraded devices, Sol. Energy Mater. Sol. Cells. 152 (2016) 118-124. doi:10.1016/j.solmat.2016.03.035.

[42] J.M. Ball, M.M. Lee, A. Hey, H.J. Snaith, Low-temperature processed meso- 
superstructured to thin-film perovskite solar cells, Energy Environ. Sci. 6 (2013) 1739. doi:10.1039/c3ee40810h.

[43] H.-S. Kim, C.-R. Lee, J.-H. Im, K.-B. Lee, T. Moehl, A. Marchioro, et al., Lead lodide Perovskite Sensitized All-Solid-State Submicron Thin Film Mesoscopic Solar Cell with Efficiency Exceeding 9\%, Sci. Rep. 2 (2012) 591. doi:10.1038/srep00591.

[44] Z. Banyamin, P. Kelly, G. West, J. Boardman, Electrical and Optical Properties of Fluorine Doped Tin Oxide Thin Films Prepared by Magnetron Sputtering, Coatings. 4 (2014) 732-746. doi:10.3390/coatings4040732.

[45] M.P. Tsang, G.W. Sonnemann, D.M. Bassani, A comparative human health, ecotoxicity, and product environmental assessment on the production of organic and silicon solar cells, Prog. Photovoltaics Res. Appl. 24 (2016) 645-655. doi:10.1002/pip.2704.

[46] R. García-Valverde, J.A. Cherni, A. Urbina, Life cycle analysis of organic photovoltaic technologies, Prog. Photovoltaics Res. Appl. 18 (2010) 535-558. doi:10.1002/pip.967.

[47] The ecoinvent database v3.1. Swiss Centre for Life Cycle Inventories, (2014).

[48] G. Sandin, G.M. Peters, M. Svanström, Life cycle assessment of construction materials: The influence of assumptions in end-of-life modelling, Int. J. Life Cycle Assess. 19 (2014) 723-731. doi:10.1007/s11367-013-0686-x.

[49] G. Doka, Life Cycle Inventories of Waste Treatment Services, Dübendorf, 2009. http://www.doka.ch/13_I_WasteTreatmentGeneral.pdf.

[50] R.K. Rosenbaum, T.M. Bachmann, L.S. Gold, M.A.J. Huijbregts, O. Jolliet, R. Juraske, et al., USEtox - the UNEP-SETAC toxicity model: recommended characterisation factors for human toxicity and freshwater ecotoxicity in life cycle impact assessment, Int. J. Life Cycle Assess. 13 (2008) 532-546. doi:10.1007/s11367-008-0038-4.

[51] M.Z. Hauschild, M. Goedkoop, J. Guinée, R. Heijungs, M. Huijbregts, O. Jolliet, et al., Identifying best existing practice for characterization modeling in life cycle impact assessment, Int. J. Life Cycle Assess. 18 (2013) 683-697. doi:10.1007/s11367-012-0489-5.

[52] M. Pizzol, P. Christensen, J. Schmidt, M. Thomsen, Impacts of "metals" on human health: a comparison between nine different methodologies for Life Cycle Impact Assessment (LCIA), J. Clean. Prod. 19 (2011) 646-656. http://www.sciencedirect.com/science/article/pii/S0959652610001800 (accessed May 21, 2015).

[53] J.B. Guinee, Handbook on life cycle assessment operational guide to the ISO standards, Int. J. Life Cycle Assess. 7 (2002) 311-313. doi:10.1007/BF02978897.

[54] R. Frischknecht, N. Jungbluth, H.-J. Althaus, G. Doka, R. Dones, T. Heck, et al., The ecoinvent Database: Overview and Methodological Framework (7 pp), Int. J. 
Life Cycle Assess. 10 (2004) 3-9. doi:10.1065/lca2004.10.181.1.

[55] P. Forster, V. Ramaswamy, P. Artaxo, T. Berntsen, R. Betts, D.W. Fahey, et al., Changes in atmospheric constituents and in radiative forcing, in: S.Q. Solomon D; Manning, M; Chen, Z; Marquis, M; Averyt, KB; Tignor, M; Miller, HL (Ed.), Clim. Chang. 2007 Phys. Sci. Basis, Cambridge University Press, Cambridge, United Kingdom, 2007: pp. 129-234. http://www.ipcc.ch/pdf/assessmentreport/ar4/wg1/ar4-wg1-chapter2.pdf.

[56] M. Hauschild, M. Goedkoop, J. Guinee, R. Heijungs, M. Huijbregts, O. Jolliet, et al., Recommendations for Life Cycle Impact Assessment in the European context - based on existing environmental impact assessment models and factors (International Reference Life Cycle Data System - ILCD handbook), Publications Office of the European Union, 2010. doi:10.2788/33030.

[57] E.J. Armendáriz-Villegas, M. de los Á. Covarrubias-García, E. Troyo-Diéguez, E. Lagunes, A. Arreola-Lizárraga, A. Nieto-Garibay, et al., Metal mining and natural protected areas in Mexico: Geographic overlaps and environmental implications, Environ. Sci. Policy. 48 (2015) 9-19. doi:10.1016/j.envsci.2014.12.016.

[58] N.A. Hassan, M. Sahani, R. Hod, N.A. Yahya, A study on exposure to cyanide among a community living near a gold mine in Malaysia., J. Environ. Health. 77 (2015) 42-8. http://www.scopus.com/inward/record.url?eid=2-s2.084925581141\&partnerID=tZOtx3y1.

[59] S. Ncube-Phiri, A. Ncube, B. Mucherera, M. Ncube, Artisanal small-scale mining: Potential ecological disaster in Mzingwane District, Zimbabwe, Jàmbá J. Disaster Risk Stud. 7 (2015). doi:10.4102/jamba.v7i1.158.

[60] A. Marcucci, H. Turton, Induced technological change in moderate and fragmented climate change mitigation regimes, Technol. Forecast. Soc. Change. 90 (2015) 230-242. doi:10.1016/j.techfore.2013.10.027.

[61] OECD/IEA, World energy trends: Energy balances of non-OECD countries, 2015. http://www.iea.org/bookshop/663-Energy_Balances_of_Non-OECD_Countries.

[62] European Commission, Renewable Energy. 2020 renewable energy targets., (2015). http://ec.europa.eu/energy/en/topics/renewable-energy (accessed February 5, 2016).

[63] M.D. Chatzisideris, N. Espinosa, A. Laurent, F.C. Krebs, Ecodesign perspectives of thin-film photovoltaic technologies: A review of life cycle assessment studies, Sol. Energy Mater. Sol. Cells. $156 \quad$ (2016) 2-10. doi:10.1016/j.solmat.2016.05.048.

[64] N. Espinosa, R.R. Søndergaard, M. Jørgensen, F.C. Krebs, Flow Synthesis of Silver Nanowires for Semitransparent Solar Cell Electrodes: A Life Cycle Perspective, ChemSusChem. 9 (2016) 893-899. doi:10.1002/cssc.201501437.

[65] S. Amarakoon, C. Vallet, M.A. Curran, P. Haldar, D. Metacarpa, D. Fobare, et al., 
Life cycle assessment of photovoltaic manufacturing consortium (PVMC) copper indium gallium (di)selenide (CIGS) modules, Int. J. Life Cycle Assess. (2017). doi:10.1007/s11367-017-1345-4.

[66] E. Carnevale, L. Lombardi, L. Zanchi, Life Cycle Assessment of solar energy systems: Comparison of photovoltaic and water thermal heater at domestic scale, Energy. 77 (2014) 434-446. doi:10.1016/j.energy.2014.09.028.

[67] S. Saremi-Yarahmadi, W. Whittow, B. Vaidhyanathan, Electromagnetic simulation studies of microwave assisted heating for the processing of nanostructured iron oxide for solar driven water splitting, Appl. Surf. Sci. 275 (2013) 65-70. doi:10.1016/j.apsusc.2013.01.124.

[68] K.K. Kelley, Contributions to the data on theoretical metallurgy XIII, Hightemperature heat-content, heat-capacity, and entropy data for the elements and inorganic compounds, U.S. Dept. of the Interior, Bureau of Mines : G.P.O., [Washington D.C.], 1960. http://digital.library.unt.edu/ark:/67531/metadc12739.

[69] O. Knop, R.E. Wasylishen, M.A. White, T.S. Cameron, M.J.M. Van Oort, Alkylammonium lead halides. Part 2. $\mathrm{CH} 3 \mathrm{NH} 3 \mathrm{PbX} 3(\mathrm{X}=\mathrm{Cl}, \mathrm{Br}, \mathrm{I})$ perovskites: cuboctahedral halide cages with isotropic cation reorientation, Can. J. Chem. 68 (1990) 412-422. doi:10.1139/v90-063.

[70] N. Onoda-Yamamuro, T. Matsuo, H. Suga, Calorimetric and IR spectroscopic studies of phase transitions in methylammonium trihalogenoplumbates (II)†, J. Phys. Chem. Solids. 51 (1990) 1383-1395. doi:10.1016/0022-3697(90)90021-7. 